\title{
PENGEMBANGAN LEMBAR KERJA SISWA (LKS) BERBASIS MODEL INKUIRI TERINTEGRASI LIFE SKILLS PADA SISWA KELAS IV SD NEGERI OEBA 3 KUPANG
}

\author{
Julhidayat Muhsam, Nuriyah \\ ${ }^{12}$ Program Studi Pendidikan Guru Sekolah Dasar \\ ${ }^{12}$ Universitas Muhammadiyah Kupang \\ E-mail: julhidayat.1.muhsam@gmail.com.,nuriyahnur43@gmail.com
}

\begin{abstract}
Abstrak
Penelitian ini bertujuan untuk mengetahui kegunaan kelayakan dalam mengembangkan Lembar Kerja Siswa (LKS) Berbasis Model Inkuiri Terintegrasi Life Skills pada Siswa Kelas IV SD Negeri Oeba 3 Kupang. Penelitian ini telah dilaksanakan di SD Negeri Oeba 3 Kupang dengan populasi siswa kelas IVA, kelas IVB. Teknik pengambilan sampel yang digunakan adalah purposive sampling, dan terpilih kelas IVB sebagai sampel. Penelitian pengembangan LKS berbasis model inkuiri terintegrasi life skills diperoleh hasil adalah sebagai berikut: Kevalidan Silabus diperoleh nilai $=3,8$ dinyatakan valid, RPP diperoleh nilai $=3,7$ dinyatakan valid, LKS diperoleh nilai $=7,4$ dinyatakan valid, angket respon siswa dengan nilai $=87 \%$ dinyatakan layak, angket respon guru dengan nilai $=94 \%$ dinyatakan sangat layak. Adapun hasil observasi keterlaksanaan pembelajaran diperoleh nilai 4 dan dinyatakan sangat baik. Hasil penelitian dapat disimpulkan bahwa LKS dengan model inkuiri terintegrasi life skills yang digunakan dalam penelitian ini adalah layak digunakan, hal ini juga dapat dilihat pada hasil validasi dari pakar dan praktisi dan angket yang dianalisis secara deskriptif.
\end{abstract}

Abstract: This study aims to determine the usefulness of feasibility in developing Student Worksheets (LKS) Based on the Integrated Inquiry Model of Life Skills in Grade IV Students of SD Oeba 3 Kupang. This research has been carried out in SD Negeri Oeba 3 Kupang with a population of students in class IVA, class IVB. The sampling technique used was purposive sampling, and IVB class was chosen as the sample. Research on the development of the worksheet based on the integrated inquiry model of life skills results obtained are as follows: The validity of the syllabus is obtained value $=3.8$ otherwise valid, RPP obtained value $=3.7$ otherwise valid, LKS obtained value $=7.4$ otherwise valid, student questionnaire responses with value $=87 \%$ declared feasible, questionnaire responses of teachers with a value $=94 \%$ declared very feasible. The results of observations of the implementation of learning obtained a value of 4 and declared very good. The results of the study concluded that the LKS with the integrated life skills inquiry model used in this study was feasible to use, this could also be seen in the validation results from experts and practitioners and the questionnaire analyzed descriptively.

Keywords: integrated inquiry life skills, LKS

\section{PENDAHULUAN}

Undang-undang Republik Indonesia nomor 20 tahun 2003 tentang sistem pendidikan nasional tercantum secara jelas mengenai tujuan pendidikan nasional, yaitu berkembangnya potensi peserta didik agar menjadi manusia yang beriman dan bertakwa kepada Tuhan Yang Maha Esa, berakhlak mulia, sehat, berilmu, cakap, kreatif, mandiri, dan menjadi warga negara yang demokratis serta bertanggung jawab (Depdiknas, 2003). Pendidikan bertujuan untuk meningkatkan kualitas masyarakat guna menghadapi persaingan global yang semakin ketat, di 
tinjau dari aspek moral dan intelektual. Pendidikan di sekolah mempunyai tujuan untuk mengubah siswa agar memiliki pengetahuan, keterampilan, dan sikap siswa sebagai bentuk perubahan perilaku hasil belajar. Perubahan perilaku dari hasil belajar siswa biasanya dilakukan guru dengan menggunakan beberapa model pembelajaran dan kegiatan praktik untuk menunjang kegiatan proses belajar. Menurut Depdiknas (2006) pelaksanaan pembelajaran biologi tingkat sekolah menengah ditekankan pada kemampuan konsep-konsep sains, kemampuan kerja ilmiah serta penerapan dalam kehidupan, dan dapat mengkomunikasikan berbagai aspek keterampilan hidup (life skills).

Banyak faktor yang mempengaruhi keberhasilan siswa, diantaranya faktor yang datang dari pribadi (internal) siswa dan yang datang dari guru sebagai pengajar (eksternal). Pembelajaran IPA memerlukan sebuah model pembelajaran dan pendekatan agar siswa dapat lebih mudah memahami materi yang diajarkan. Proses pembelajaran pada prinsipnya merupakan proses pengembangan moral spiritual, aktivitas dan kreatifitas siswa melalui berbagai interaksi dan pengalaman belajar. Namun, dalam implementasinya masih banyak kegiatan pembelajaran yang mengabaikan aktivitas dan kreatifitas siswa tersebut. Hal ini disebabkan oleh model pembelajaran yang lebih menekankan pada penguasaan kemampuan intelektual (kognitif) saja dan proses pembelajarannya terpusat pada guru (teacher center) dimana siswa hanya menunggu penjelasan dari guru, kemudian mencatat dan menghafalnya.

Model pembelajaran dalam IPA harus mengubah situasi guru mengajar kepada situasi siswa belajar. Guru memberikan pengalamannya kepada siswa sebagai pengayom, sebagai sumber tempat bertanya, sebagai pengarah, sebagai pembimbing, sebagai fasilitator dan sebagai organisatoris dalam belajar. Guru harus memperlakukan siswa dengan penuh kasih sayang, membimbing ke arah selalu ingin tahu dan tidak lekas puas dengan hasil yang dicapai. Guru harus memberi kesempatan yang cukup kepada siswa untuk belajar melakukan sendiri, merasakan sendiri, berpikir bebas pola-pola relasi (hubungan) dalam biologi, hubungan dengan mata pelajaran lain serta kehidupan masyarakat di alam sekelilingnya dan latihan keterampilan yang diperlukannya.

Model inkuiri merupakan rangkaian pembelajaran yang menekankan pada proses berpikir secara kritis dan analitis untuk mencari dan menemukan sendiri jawaban dari suatu masalah yang dipertanyakan (Sanjaya, 2006). Tujuan utama model inkuiri adalah mengembangkan kemampuan berpikir sehingga model ini selain berorientasi pada hasil belajar, juga berorientasi pada proses belajar.

Pentingnya pendidikan berbasis kecakapan hidup (life skills) dalam kehidupan dan pendidikan adalah untuk membekali siswa bekal dasar dan latihan-latihan yang dilakukan secara benar tentang program keterampilan yang dicanangkan menjadi sangat penting bagi siswa dan guru. Proses pembelajaran yang dapat menciptakan siswa aktif dalam kegiatan belajar mengajar di kelas yaitu dengan menggunakan lembar kerja siswa. LKS tersebut dapat digunakan untuk mengembangkan ranah pengetahuan dan ranah keterampilan serta sikap siswa. Oleh karena itu, perlu diterapkan model pembelajaran yang tepat dalam meningkatkan hasil belajar siswa khususnya pada mata pelajaran biologi, yang salah satunya yaitu dengan mengembangkan LKS berbasis model inkuiri dan memasukkan life skills di dalamnya.

\section{METODE}

Instrumen yang digunakan dalam penelitian ini adalah instrumen pembelajaran (perangkat pembelajaran) dan instrumen pengumpulan data. Sampel dalam penelitian terdiri dari kelas IVB yang berjumlah 24 orang.

Pengembangan LKS IPA menggunakan model berbasis inkuiri terintegrasi life skills. Dalam penelitian ini menggunakan model prosedural yang mengadopsi model 4-D dari Thiagarajan, Dorothy S. Semmel dan Melvyn I. Semmel (1974), yaitu: 1) tahap pendefinisian; 2) tahapan perancangan (design); 3) tahap pengembangan (develop); 4) tahap penyebaran 
(disseminate). Penelitian pengembangan dilakukan hanya sampai tahap develop, mengingat tujuan penelitian adalah mengetahui kelayakan LKS berbasis model inkuiri terintegrasi life skills.

Pada penelitian ini, terdapat dua teknik analisis deskriptif yang dilakukan yaitu: 1) deskriptif kualitatif berdasarkan skor data dari validasi ahli materi IPA, ahli pengembangan LKS, uji perorangan, dan uji coba lapangan berupa masukan, tanggapan, saran, dan kritik perbaikan yang terdapat pada angket. Hasil analisis ini kemudian digunakan untuk merevisi produk pengembangan. Teknik analisis ini digunakan untuk mengolah data yang diperoleh melalui lembar validasi LKS, dengan rumus sebagai berikut:

$$
\mathrm{X}=\frac{\sum \mathrm{x}}{\mathrm{N}}
$$

Keterangan:

$\mathrm{X}=$ skor rata-rata

$\sum \mathrm{x}=$ jumlah skor

$\mathrm{N}=$ jumlah butir/subkomponen

Kriteria penilaian ahli, LKS dinyatakan lolos apabila komponen kelayakan isi mempunyai rata-rata skor minimal 2,75 pada setiap komponen. Sedangkan pada komponen kebahasaan dan penyajian mempunyai rata-rata skor lebih besar dari 2,50 pada setiap subkomponen. LKS dinyatakan lolos dengan perbaikan apabila komponen isi, kebahasaan dan penyajian mempunyai rata-rata skor kurang dari atau sama dengan 2,50 pada setiap subkomponen. LKS dinyatakan tidak lolos apabila mempunyai rata-rata skor sama dengan 1 pada setiap komponen. Kriteria penilaian disajikan pada tabel 1.

\begin{tabular}{|c|c|c|}
\hline Komponen & Skor & Kriteria \\
\hline \multirow{4}{*}{$\begin{array}{l}\text { Isi } \\
\text { Kebahasaan } \\
\text { Penyajian }\end{array}$} & $\bar{X} \geq 2,75$ & Lolos \\
\hline & $\bar{X}>2,5$ & Lolos \\
\hline & $\bar{X} \leq 2,5$ & Lolos dengan perbaikan \\
\hline & $\bar{X}=1$ & Tidak lolos \\
\hline
\end{tabular}

Tabel 1. Kriteria Penilaian Validasi Ahli

(BSNP, 2007 dalam Sugianto, 2013)

2) deskriptif kuantitatif digunakan untuk mengolah data yang diperoleh dalam bentuk prosentase. Teknik prosentase digunakan untuk menyajikan data yang merupakan frekuensi atas tanggapan subjek uji coba terhadap produk LKS. Teknik analisis ini digunakan untuk mengolah data yang diperoleh melalui angket dalam bentuk prosentase dari masing-masing subjek.

Penentuan jenis pilihan jawaban dari angket dengan menggunakan skala likert melalui 3 kategori jawaban. Jawaban setiap item instrument yang menggunakan skala likert mempunyai gradiasi yang sangat positif sampai sangat negatif, yang dapat berupa kata-kata. Untuk lebih jelasnya dapat dilihat pada Tabel 2 sebagai berikut: 
Tabel 2. Skor Jawaban untuk Setiap Item

\begin{tabular}{|c|l|c|}
\hline No & Pilihan jawaban & $\begin{array}{l}\text { Pilihan } \\
\text { jawaban }\end{array}$ \\
\hline 1 & Selalu & 4 \\
2 & Kadang-kadang & 3 \\
3 & Tidak pernah & 2 \\
\hline
\end{tabular}

Sumber: Sudjana (2004)

Selanjutnya untuk menghitung prosentase keseluruhan subjek/komponen digunakan rumus:

$$
\mathrm{P}=\frac{\sum \mathrm{p}}{\mathrm{n}}
$$

Keterangan: $\sum \mathrm{p}=$ Jumlah prosentase keseluruhan komponen. $\mathrm{N}=$ Banyak komponen.

Tabel 3. Kriteria Validitas dalam Pengambilan Keputusan Revisi Pengembangan:

\begin{tabular}{|l|l|l|}
\hline $\begin{array}{l}\text { Tingkat } \\
\text { Pencapaian }\end{array}$ & Kualifikasi & Keterangan \\
\hline $85 \%-100 \%$ & Sangat Valid & Tidak perlu direvisi \\
\hline $70 \%-84 \%$ & Valid & Tidak perlu direvisi \\
\hline $55 \%-69 \%$ & Cukup Valid & Tidak perlu direvisi \\
\hline $50 \%-54 \%$ & Kurang Valid & Perlu direvisi \\
\hline $0 \%-49 \%$ & Tidak Valid & Perlu direvisi \\
\hline
\end{tabular}

Tabel diadaptasi dari Purwanto (2005).

Berdasarkan Tabel 3 tersebut diatas, apabila hasil analisis validasi telah mencapai $\geq$ 70\% maka penerapan LKS berbasis model inkuiri terintegrasi life skills sudah dapat dikatakan layak sebagai bahan ajar. Sedangkan jika hasil analisis validasi $\leq 54 \%$, maka penerapan LKS berbasis model inkuiri terintegrasi life skills belum layak untuk digunakan dan harus dilakukan revisi terlebih dahulu.

\section{HASIL DAN PEMBAHASAN}

Penelitian yang telah dilakukan merupakan penelitian pengembangan yang bertujuan untuk mengembangkan LKS berbasis model inkuiri terintegrasi life skills pada mata pelajaran biologi. Adapun tujuan dari penelitian adalah mengetahui kelayakan LKS berbasis model inkuiri terintegrasi life skills pada mata pelajaran IPA.

Pada subbab hasil penelitian ini akan disajikan proses pengembangan LKS, validasi LKS oleh para pakar, dan uji coba LKS. LKS yang dikembangkan telah melalui tahap-tahap pengembangan sesuai model atau prosedur pengembangan yang ada.

Penelitian pengembangan LKS berbasis model inkuiri terintegrasi life skills pada mata pelajaran IPA mengikuti tahapan penelitian pengembangan berdasarkan Thiagarajan, Semmel dan Semmel (dalam Trianto, 2012) yaitu model 4-D, yang terdiri dari 4 tahap pengembangan yaitu define, design, develop, dan disseminate.

Validasi dilakukan menggunakan instrumen lembar validasi LKS. Validasi dilakukan oleh dosen dari Universitas Muhammadiyah Kupang dan Guru Mapel dari SD Negeri Oeba 3 Kupang ( 1 orang dosen biologi dan 1 orang guru mapel IPA). Hasil dari validasi produk akan disajikan pada Tabel 4. 
Tabel 4. Data Hasil Validasi LKS oleh Ahli.

\begin{tabular}{|l|l|l|l|l|l|}
\hline \multirow{2}{*}{ No } & \multirow{2}{*}{ Kelayakan } & \multicolumn{2}{|l|}{ Validator } & \multirow{2}{*}{ Kriteria } \\
\cline { 3 - 5 } & & $\mathbf{V 1}$ & $\mathbf{V 2}$ & Total & \\
\hline 1 & Isi yang disajikan & 3,3 & 3,5 & 6,8 & Layak \\
\hline 2 & Bahasa & 4 & 4 & 8 & Sangat Layak \\
\hline Rata-rata & & & 7,4 & Sangat Layak \\
\hline
\end{tabular}

Berdasarkan tabel 5 tentang hasil validasi dari dosen dan guru mapel IPA secara keseluruhan mendapatkan hasil yang sangat layak dengan pencapaian skor rata-rata adalah 7,4. LKS telah dinyatakan lolos dan layak digunakan dalam kegiatan pembelajaran. Dari semua aspek penilaian mendapat nilai lebih dari 2,75 dan LKS dapat dikategorikan layak digunakan tanpa revisi. Adapun data Hasil Lembar Observasi Keterlaksanaan pembelajaran inkuiri terintegrasi life skills.

Tabel 5. Data Hasil Lembar Observasi Keterlaksanaan Pembelajaran Inkuiri Terintegrasi Life Skills.

\begin{tabular}{|l|l|l|l|}
\hline No & Aspek Pengamatan & Total skor & Kriteria \\
\hline 1 & Kegiatan Awal & 16 & Sangat Baik \\
\hline 2 & Kegiatan Inti & 32 & Sangat Baik \\
\hline 3 & Penutup & 24 & Sangat Baik \\
\hline \multicolumn{2}{|l|}{ Rata-rata } & $\mathbf{4}$ & Sangat Baik \\
\hline
\end{tabular}

Berdasarkan Tabel 5 tentang hasil observasi keterlaksanaan pembelajaran dari guru mapel IPA, LKS telah terlaksana dengan sangat baik. Dari semua aspek pengamatan mendapat nilai rata-rata adalah 4 dan pelaksanaan pembelajaran yang dilaksanakan di kelas sudah sangat baik.

Tabel 6. Saran dan Perbaikan LKS oleh Guru

\begin{tabular}{|l|l|l|}
\hline No & Saran & Perbaikan \\
\hline 1 & $\begin{array}{l}\text { LKS (materinya) harus disesuaikan } \\
\text { dengan silabus dan KD agar target } \\
\text { pembelajaran terapai }\end{array}$ & $\begin{array}{l}\text { Materi pada sudah disesuaikan } \\
\text { dengan silabus }\end{array}$ \\
\hline
\end{tabular}

\section{Hasil Respon atau Tanggapan Siswa dan Guru}

LKS berbasis model inkuiri terintegrasi life skills selanjutnya dilakukan uji coba. Uji coba dilakukan di SD Negeri Oeba 3 Kupang dengan melibatkan seluruh siswa kelas IVB. Uji coba dengan membagikan LKS berbasis model inkuiri terintegrasi life skills kepada siswa dan meminta mereka membaca, mempelajari, dan mengisi angket yang berisi respon terhadap LKS berbasis model inkuiri terintegrasi life skills. Penilaian diambil dengan menggunakan angket dengan jumlah item 25 butir. Tanggapan siswa terhadap LKS berbasis model inkuiri terintegrasi life skills dapat dilihat pada tabel 7.

Tabel 7. Hasil Respon/Tanggapan Siswa Terhadap LKS

\begin{tabular}{|l|l|l|}
\hline Aspek & Rata-rata (\%) & Kriteria \\
\hline Kelayakan LKS secara keseluruhan & 87 & Layak \\
\hline
\end{tabular}

Berdasarkan Tabel 7 dapat dilihat bahwa respon siswa terhadap LKS yang diberikan terkait LKS berbasis model inkuiri terintegrasi life skills secara keseluruhan mendapatkan respon sangat baik dengan pencapaian skor penilaian rata-rata adalah $87 \%$. Hal ini menunjukkan bahwa penerapan LKS berbasis model inkuiri terintegrasi life skills sudah dapat dikatakan layak untuk digunakan tanpa harus dilakukan revisi tahap II.

Data selanjutnya ada kegiatan uji coba adalah tanggapan/respon guru. Data tanggapan guru terkait LKS berbasis model inkuiri terintegrasi life skills dalam pembelajaran meliputi 14 
aspek. Tanggapan guru IPA terhadap LKS berbasis model inkuiri terintegrasi life skills dapat dilihat pada tabel 8 .

Table 8. Hasil Respon/Tanggapan Guru Terhadap LKS

\begin{tabular}{|l|l|l|}
\hline Aspek & $\begin{array}{l}\text { Rata-rata } \\
(\boldsymbol{\%})\end{array}$ & Kriteria \\
\hline Kelayakan LKS secara keseluruhan & 94 & Sangat Layak \\
\hline
\end{tabular}

Berdasarkan Tabel 8 tentang tanggapan/respon guru terhadap LKS menyatakan bahwa LKS termasuk dalam kategori "sangat layak", hal ini ditunjukkan dari empat belas aspek dalam angket yang ditanyakan kepada guru mapel, tidak terdapat aspek yang dijawab "kurang baik atau tidak baik" oleh guru mapel. Jumlah porsentase total yang diperoleh dari tanggapan guru adalah $94 \%$.

\section{Pembahasan Hasil Penelitian}

Penelitian ini bertujuan untuk mengembangkan LKS berbasis model inkuiri terintegrasi life skills. Proses validasi LKS oleh para pakar, data tanggapan guru, data tanggapan siswa terhadap LKS berbasis model inkuiri terintegrasi life skills. Peran LKS dalam pembelajaran menurut Widjajanti (2008) LKS selain sebagai media pembelajaran juga mempunyai beberapa fungsi lain, yaitu: 1) merupakan alternatif bagi guru untuk mengarahkan pengajaran atau memperkenalkan sesuatu kegiatan tertentu sebagai kegiatan belajar mengajar; 2) dapat digunakan untuk mempercepat proses pengajaran dan menghemat waktu penyajian suatu topik; 3) dapat digunakan untuk mengetahui seberapa jauh materi yang telah dikuasai siswa; 4) dapat mengoptimalkan alat bantu pengajaran yang terbatas; 5) membantu siswa lebih aktif dalam proses belajar mengajar; 6) dapat membangkitkan minat siswa jika LKS disusun secara rapi, sistematis, dan mudah dipahami oleh siswa sehingga menarik perhatian siswa; 7) dapat menumbuhkan kepercayaan pada diri siswa dan meningkatkan motivasi belajar dan rasa ingin tahu; 8) dapat mempermudah penyelesaian tugas perorangan, kelompok karena siswa dapat menyelesaikannya tugas sesuai dengan kecepatan belajarnya; 9) dapat digunakan untuk melatih siswa menggunakan waktu seefektif mungkin; 10) dapat meningkatkan kemampuan siswa dalam memecahkan masalah.

Pembahasan Hasil Tahap Pendefiisian (define): Berdasarkan analisis masalah yaitu: 1) siswa belum mampu memahami konsep secara mandiri; 2) motivasi belajar siswa dalam mengikuti pelajaran biologi sangat rendah; 3) siswa kurang aktif dalam menemukan konsep secara mandiri; dan 4) pembelajaran biologi masih menggunakan LKS berbasis konvensional, belum menggunakan model pembelajaran tertentu. Hal ini menunjukkan bahwa langkah awal dalam pengembangan LKS berbasis model inkuiri terintegrasi life skills adalah dengan melakukan studi pendahuluan. Studi pendahuluan dari produk pengembangan adalah dengan mengkaji literatur tentang tujuan pembelajaran yang akan dicapai yaitu meningkatkan hasil belajar siswa. Bahan ajar yang digunakan berupa LKS, serta menentukan model pembelajaran yang akan digunakan yaitu model inkuiri terintegrasi life skills.

Pembahasan Hasil Tahap Perancangan (design): Setelah dilakukan tahap define, maka selanjutnya dilakukan tahap design. Tahap design (perancangan) merupakan tahap penyusunan LKS yang diawali dengan menyusun silabus, RPP, dan kisi-kisi soal. LKS berbasis model inkuiri terintegrasi life skills yang dikembangkan sesuai dengan KI dan KD suatu pokok bahasan yang akan diajarkan pada siswa kelas IV SD Negeri Oeba 3 Kupang. LKS berbasis model inkuiri terintegrasi life skills mrupakan LKS yang bertujuan untuk melatih dan menuntun siswa menggali informasi atau konsep pengetahuan yang ingin dicari. Pembahasan Hasil Tahap Pengembangan (develop): 1) Validasi Ahli, validasi LKS yang dilakukan oleh dosen dan guru pakar. Saran-saran yang diberikan oleh validator diantaranya adalah perangkat yang dibuat sudah baik tetapi perlu diperhatikan kompetensi dasarnya. 
Berdasarkan Tabel 5 LKS berbasis model inkuiri terintegrasi life skills selanjutnya dilakukan uji coba. Uji coba dilakukan di SD Negeri Oeba 3 Kupang dengan melibatkan seluruh siswa kelas IVB. Uji coba dengan membagikan LKS berbasis model inkuiri terintegrasi life skills kepada siswa dan meminta mereka membaca dan mempelajarinya, kemudian mereka diminta mengisi angket yang berisi respon terhadap LKS berbasis model inkuiri terintegrasi life skills. Penilaian diambil dengan menggunakan angket dengan jumlah item 25 butir. Selanjutnya adalah tanggapan/respon guru. Data tanggapan guru terhadap LKS berbasis model inkuiri terintegrasi life skills dalam pembelajaran meliputi 14 aspek. Penilaian dilakukan oleh guru biologi kelas IV SD Negeri Oeba 3 Kupang.

Respon guru dan siswa terhadap LKS berbasis model inkuiri terintegrasi life skills ratarata adalah sangat baik. Dengan demikian LKS berbasis model inkuiri terintegrasi life skills dapat dikatakan sudah baik dan layak untuk digunakan tanpa revisi pada tahap II. Hal ini sesuai dengan penelitian yang dilakukan oleh Millah (2012), penyajian permasalahan autentik diperlukan untuk membangun life skills siswa agar konsep-konsep yang ada dalam buku ajar tersebut dapat diterapkan dalam kehidupan sehari-hari.

Berdasarkan aspek yang direspon pada angket tanggapan guru diperoleh saran bahwa dalam menyusun LKS dimana di dalamnya tercantum silabus, KI, KD, dan materi agar semuanya sesuai sehingga tujuan pembelajaran yang sesuai dengan KD dapat tercapai. Hal ini ditunjukkan pada aspek yang direspon pada angket tanggapan guru. Berdasarkan saran dan masukan yang diperoleh melalui angket respon guru terhadap LKS, maka LKS disarankan untuk di perbaiki.

Berdasarkan perolehan skor validasi LKS dalam kategori sangat baik, yaitu validasi LKS yang dilakukan oleh dosen dan guru IPA. Dari semua aspek penilaian mendapat nilai rata-rata adalah 7,4 dan LKS dikategorikan layak digunakan tanpa revisi. Analisis kelayakan bahan ajar menurut BSNP dalam Trian (2013), yaitu jika hasil skor telaah penilaian bahan ajar menggunakan standar penilaian BSNP minimal mencapai 2,75 untuk komponen kelayakan isi, dan 2,50 untuk komponen kebahasaan dan penyajian.

Siswa merasa pembelajaran menggunakan LKS berbasis model inkuiri terintegrasi life skills sangat bermanfaat, hal ini didasarkan pada data tanggapan siswa terhadap LKS yang memperoleh porsentase rata-rata sebesar $87 \%$ (Sangat Layak). Siswa menganggap LKS berbasis inkuiri terintegrasi life skills sangat baik digunakan dalam proses pembelajaran.

LKS berbasis model inkuiri terintegrasi life skills merupakan LKS yang bertujuan untuk memberikan pengetahuan dan keterampilan siswa dalam menguasai materi. Dengan demikian LKS berbasis model inkuiri terintegrasi life skills dapat dikatakan secara umum sudah baik dan layak untuk digunakan.

\section{KESIMPULAN}

LKS berbasis model inkuiri terintegrasi life skills pada materi linkungan layak digunakan sebagai sumber belajar karena mendapat nilai rata-rata kelayakan dari validator dengan skala penilaian sangat baik. LKS berbasis model inkuiri terintegrasi life skills dapat diterapkan dalam pembelajaran di sekolah karena nilai rata-rata tanggapan/respon siswa sebesar $87 \%$ dengan kriteria sangat dapat diterapkan.

Berdasarkan hasil penelitian, dapat disampaikan saran demi kelancaran dan perbaikan kegiatan pengembangan bahan ajar selanjutnya, sebagai berikut:

1. Dalam penelitian ini hanya meneliti kelayakan LKS berbasis model inkuiri terintegrasi life skills. Oleh karena itu, penelitian ini dapat diteruskan untuk melihat efektifitas dan efesiensi LKS dalam kegiatan pembelajaran.

2. Penelitian selanjutnya dapat dilakukan dengan mengembangkan bahan ajar dengan menggunakan model yang berbeda, sehingga dapat meningkatkan kualitas pembelajaran. 


\section{DAFTAR PUSTAKA}

Badan Standar Nasional Pendidikan \& Departemen Pendidikan Nasional. 2006. Contoh/Model Silabus Mata Pelajaran Ilmu Pengetahuan Alam Sekolah Menengah Pertama. Departemen Pendidikan Nasional. Jakarta

BSNP. 2007. Media Komunikasi dan Dialog Standar Pendidikan. Buletin BSNP

Depdiknas. 2003. Pedoman Pengembangan Instrumen dan Penilaian Rana Afektif. Drektorat Pendidikan Menengah Umum Depdiknas. Jakarta

Depdiknas. 2006a. Pengembangan Model Pendidikan Kecakapan Hidup Puskur Balitbang Depdiknas . www.puskur.net

Depdiknas. 2006b. Standar Isi Kurikulum Tingkat Satuan Pendidikan. Departemen Pendidikan Nasonal. Jakarta

Sanjaya. 2006. Strategi pembelajaran. Kencana Pernada Media. Bandung

Sudjana, N. 2004. Dasar-dasar Proses Belajar Mengajar. Sinar Baru Algesindo. Bandung.

Trian, E.A dkk. 2013. Pengembangan Modul IPA Terpadu Berkarakter pada Tema Pengelolaan Lingkungan untuk Kelas VII SMP. Unnes Science Education Journal, 2(2) $: 271$

Trianto. 2007. Model Pembelajaran Terpadu dalam Teori dan Praktek.Prestasi Pustaka. Jakarta

Trianto. 2009. Mendesain Model Pembelajaran Inovatif-Progresif: Konsep, Landasan, dan Implementasinya pada Kurikulum Tingkat Satuan Pendidikan (KTSP). Prenada Media Group. Jakarta

Trianto. 2012. Model Pembelajaran Terpadu. Bumi Aksara. Jakarta

Undang-Undang Republik Indonesia Nomor 20 Tahun 2003 tentang Sistem Pendidikan Nasional. 2003. PT Armas Duta Jaya. Jakarta 